\title{
MACMILLAN ENGLISH DICTIONARY: THE END OF PRINT?
}

\section{Michael RUNDELL}

Lexicography MasterClass and Macmillan Dictionaries

Rundell, M. (2014): Macmillan English Dictionary: The End of Print? Slovenščina 2.o, 2 (2):

$1-14$.

URL: http://www.trojina.org/slovenscina2.o/arhiv/2014/2/Slo2.o_2014_2_o2.pdf.

This paper reports on the Macmillan English Dictionary (MED) and its transition from printed book to digital-only resource. The background to this decision is explained in terms of changes both in technology and in dictionary-users' behaviour: was this move inevitable, and will other dictionary publishers follow (sooner or later)? The possible downsides of abandoning print are discussed, alongside the advantages of digital media. As well as offering great opportunities (many still unexplored), being online also creates new demands. With easy access to numerous free reference sites, users searching for lexical information have a huge variety of options. Consequently, publishers are under pressure to continually broaden the range of content they supply, to improve the quality of the design and "user experience", and above all to stay abreast of language change. And, it will be shown, there is much more to keeping a dictionary up to date than simply adding new words as they emerge. The imperative of moving to digital has generated a good deal of turbulence in the world of dictionary publishing (especially for commercial publishers who cannot run at a loss), and there is considerable uncertainty around the long-term survival of "the dictionary" as the autonomous object we are all familiar with. But humans' communicative needs should ensure a continued demand for high-quality lexical data - even if this data is delivered and accessed in new and different ways.

Keywords: print dictionary, digital media, Web 2.o, inclusion, updating 


\section{MIGRATING FROM PRINT TO DIGITAL: WILL DICTIONARIES FOLLOW ENCYCLOPEDIAS?}

It seems unlikely that many people feel nostalgic for those big multi-volume encyclopedias which used to adorn every library and appear in many homes. Factual reference materials made the transition from printed book to digital resource quite quickly, and with little sign of regret on the part of their users. On the contrary: people looking for encyclopedic information have embraced digital media enthusiastically, and the vast majority of inquiries of this type will start with a query in a search engine. This may or may not take you to something that vaguely resembles an encyclopedia (Wikipedia being the most likely destination), but there are big differences between the older and newer media. With hyperlinking, unlimited space, and the capacity for almost instant updating, it seems obvious that digital formats are far better adapted to provide factual information, and that the printed book was an interim technology waiting for a better one to come along. For, as Hilary Nesi has observed (Nesi, forthcoming), reference materials aren't like other books: "People typically consult maps, encyclopedias, and dictionaries while they are doing something else".

It would be reasonable to imagine that dictionaries would follow a similar trajectory. But in this case the migration from print to digital has been slower and more controversial, and it is still far from complete. In the case of encyclopedias, the main concern regarding digital resources was whether they could match traditional print versions for reliability. With dictionaries, other factors are in play. At the end of 2012, when Macmillan announced ${ }^{1}$ that it would no longer be producing physical dictionaries and would focus on its digital assets, we concluded that dictionaries had "found their ideal medium". This set off an animated debate on the Macmillan blog, on social media, and especially on the EURALEX discussion list. And while many agreed that the end

${ }^{1}$ http://www.macmillandictionaryblog.com/bye-print-dictionary 
of printed dictionaries was an inevitable - and positive - development, many others took a different view, and saw this as a "a sad day" for lexicography. Perhaps people are more invested in dictionaries because almost everyone owns one (most are smaller and more portable than the average encyclopedia). And the dictionary seems to be a more salient cultural artefact than the encyclopedia: dictionaries are still widely perceived as performing a "gatekeeper" role with regard to language change, so that a novel or disputed usage gains status by being admitted to "The Dictionary". Whatever the reasons, there remains a good deal of resistance to the notion that dictionaries should follow encyclopedias down the route to a digital-only future.

\section{THE TECHNOLOGICAL BACKGROUND}

There are two main drivers behind Macmillan's decision to abandon paper dictionaries: developments in technology, and (related) changes in the behaviour and expectations of dictionary users. Dictionaries have been available in digital form since the 1980 s (if not earlier). They initially took the form of small, handheld devices produced by consumer electronics companies such as Sharp and Casio, which imported the data from existing printed dictionaries, with little adaptation of either presentation or content. Dictionaries on CD-ROM followed from the end of the 1980s, and the Longman Interactive American Dictionary - the first electronic English learner's dictionary - appeared in 1993 (Nesi 2009: 460-469). Despite some added functionality (such as improved search facilities, hyperlinked cross-references, and audio pronunciations) and in some cases a limited amount of new content (exercises, videos), these early attempts at digitization were fairly conservative. Rather in the way that the first cars resembled pre-existing horse-drawn carriages - but without the horse - dictionaries on CD-ROMs continued to look very like the print dictionaries they sprang from. Until well into the noughties, the printed book remained the primary focus for both publishers and users. The CD-ROM dictionary was seen by both parties as a must-have adjunct to the 
paper edition - but no more than an adjunct - and progress in exploiting the potential of the new medium was slow. The behaviour of dictionary purchasers mirrored this: they expected their paper dictionary to come with a CD-ROM, but many publishers are sceptical about how much these were actually used. Thus, following the model of what is sometimes called "sustaining innovation", the digital dictionaries of the 1990 s and 2000 s had relatively little impact either on the business of dictionary publishing, or on the way users searched for lexical information.

It was the arrival of fast, mass-scale, always-on Internet connections that sparked more fundamental changes: the new, central role of the search engine in any kind of information-retrieval, opportunities for interaction between producers and consumers, and - shortly after - the rise of social media. This process, often characterized under the coverall term Web 2.o, began at the start of the new millennium and accelerated from around 2005. Unlike earlier forms of electronic media, these were disruptive technologies which created entirely new types of business. The dictionary market was not immune. It was against this background that Macmillan took its decision to stop producing printed dictionaries and focus its attention on digital media.

\section{WHY MACMILLAN STOPPED PRINTING DICTIONARIES - AND HOW USERS REACTED}

The Macmillan English Dictionary (MED) was originally published in 2002 as a book and CD-ROM, and quickly established itself as a leading player in the already crowded market for monolingual learner's dictionaries of English. Both components of the dictionary picked up prestigious awards: the English Speaking Union's “Duke of Edinburgh English Language Book Award” (2002) was followed in 2004 by the British Council's "ELTon" award for digital innovation. A second edition (now with a thesaurus on the CD ROM) was published in 2007. At that point there was no thought of abandoning the print medium. Indeed, we started planning a third edition ("MED3") from the 
moment the second edition went to the printers. An online version ${ }^{2}$ of the dictionary went live at the beginning of 2009, providing a digital alternative to the still-popular printed book. But the world was changing quickly, and over the next three years we found that sales of books began to decline in a way that looked irreversible, while traffic to the new website was growing rapidly. As recently as the mid-2000s two of the strongest markets for MED were Japan and Korea, but within a few years sales in this region had tumbled. This is hardly surprising - it is difficult to imagine a 19-year-old student from either country, with a communicative problem to resolve, reaching a book down from the shelf. But the speed of this change took most of us in the business by surprise.

Could we have our cake and eat it - maintaining revenue from book sales, while gaining a new income stream from the dictionary website? Possibly yes, in the short term, but the maths are complicated. It seems unlikely that many users would need (or want) both media. The market probably divides between those who live in areas of high connectivity (especially the digital natives among them), and people living in places where access to the Web is still limited and/or expensive. You would expect the first group (which includes Japan and Korea) to favour the digital dictionary, while the second group still depends on the printed one. (One of MED's well-known competitors has a model where an online version exists, but is only available to people who have already bought the print version of the dictionary; this doesn't look like a coherent strategy, and I would be surprised if it works.) There are all sorts of other variables. For example, in some smaller markets where annual dictionary sales were already low, the cost of making the books available (which includes transportation and deals with local distributors) could in some cases exceed the revenue from sales. Taking everything together, Macmillan concluded that, for dictionaries, the trend away from books and towards digital media was heading in only one 
direction. Sooner or later, print dictionaries of general English were going to become unsustainable, and there may be advantages in getting ahead of the curve, embracing the change rather than resisting it, and focusing - without distractions - on the opportunities which the new medium offered. Whether Macmillan got the timing exactly right is a matter for conjecture. But the strategy is undoubtedly the right one.

That is not to say everyone is happy about the migration of dictionaries from print to digital media. I have discussed elsewhere the various objections to ending the production of paper dictionaries (e.g. Rundell 2013; blog post at http://www.macmillandictionaryblog.com/no-more-print-dictionaries) and most of the arguments are easily countered. What might be called the "sentimental" argument, reflecting people's attachment to dictionaries as familiar and well-liked artefacts, came up several times in discussions following Macmillan's announcement. There is, it is true, a community of people who simply "love words" (sometimes known as "logophiles") - the kind of people who will be thrilled to hear about the recent 12th edition (late 2014) of the Collins English Dictionary, and to learn that "now you can look up the word slumbersome (meaning sleepy), or dreamwhile (the duration of a dream), or eyesome (meaning beautiful)". 3 One can appreciate that print dictionaries would remain important to people with these predilections. But a quick corpus check confirms that these three "new" words are spectacularly rare - no one would ever need to look them up "in real life" - so their main function in the dictionary is to give the logophiles something to enthuse about. This is all harmless fun, no doubt, but the Macmillan Dictionary, like others of its type, has very different objectives. It is a practical tool designed primarily to meet the communicative needs of people whose mother tongue is not English but who use English in their work or studies. This is a quite different user-group, and for most of them the sentimental argument has little resonance. 
Given the massive advantages of moving dictionaries to digital media (on which, more below), the only serious objection to doing it is around connectivity: the lack of affordable and extensive Web connections in some parts of the world means that some users will no longer have access to the dictionary if the print version is discontinued. This argument is not without merit. But the idea that thousands of users are being heartlessly deprived of dictionaries fails to recognise that, in the poorest parts of the world, only the more affluent were ever in a position to pay for (relatively expensive) printed dictionaries when those were the norm. As Web infrastructure steadily improves worldwide, the (free) online dictionary will become available to larger numbers than ever before. In any event, it is clear that we are in a transitional phase, where Internet access is continually expanding and will eventually be more or less ubiquitous. For example, in sub-Saharan Africa - already saturated with mobile phones - users are steadily upgrading to Web-connected smartphones, and this model is replicated in many less affluent economies. The direction of travel is clear, and as the percentage of people with good Web connections grows ever higher, the connectivity argument becomes less and less relevant.

\section{WHY DIGITAL DICTIONARIES ARE BETTER}

Digital media offer extraordinary opportunities for improving dictionaries, and these comprehensively outweigh any downsides to moving from print to online. These innovations have been widely discussed, and in Macmillan's case the cumulative effect has been a redefinition of what we mean by the word "dictionary". In its original print edition (2002), Macmillan defined dictionary (in its main sense) as

a book that gives a list of words in alphabetical order and explains what they mean

This is not an adequate description of any online dictionary: they are not "books"; alphabetical order is irrelevant (it was just a useful convention for 
organizing and finding words in the print medium); and explaining what words mean is only one of numerous functions. Macmillan's current definition of dictionary reads:

a reference resource which provides information about words and their meanings, uses, and pronunciations. A dictionary may be published as a printed book, or as a digital product such as a website or app, and it may be monolingual, bilingual, or multilingual.

Even this expanded description fails to tell the whole story. Like many other online "reference resources", MED supplies a range of material which goes far beyond the traditional focus of "the dictionary". This includes content such as language games, pedagogically-oriented videos, downloadable teaching materials, a weekly column on new words, 4 and an active blog5 with regular contributions on a variety of language issues from both Macmillan's own editors and over a hundred guest bloggers.

With regard to the dictionary itself (in the narrow, traditional sense), the clearest advantages of going digital are, first, that our inclusion policy (deciding what goes in the dictionary) is less restrictive now that we are no longer constrained by limits on space; and second, that the dictionary can be kept truly current, through a programme of regular updates.

Even the largest print dictionaries need clear policies on inclusion: there will always be more vocabulary out there than a physical dictionary can accommodate, and the mighty OED itself concedes that its coverage is far from comprehensive. For single-volume paper dictionaries, strict entry criteria apply, informed by a well designed user-profile: who will use the dictionary, what will they use it for, and what kinds of vocabulary will they need to know about? Even then, tough decisions have to be made. Anyone with experience of doing a major new edition of an existing title will be familiar with the

4 http://www.macmillandictionary.com/buzzword/aboutbuzzwords.html

5 www.macmillandictionaryblog.com 
compromises that had to be made: which older items could be safely jettisoned to make room for new words and meanings? how far could new material be absorbed by increasing the number of pages (a process which cannot go on indefinitely)? how many of the novel vocabulary items collected since the previous edition might turn out to be fairly ephemeral? And so on. All of this changes in the digital medium. That doesn't mean we can dispense with an inclusion policy altogether, and randomly admit anything, but some rethinking of well-established principles is clearly needed, and this is far from straightforward.

Keeping the dictionary up to date is the most obvious benefit of being online rather than on paper. In the old dispensation, dictionaries would typically be updated once every four or five years. But the consequence was that your dictionary was already out of date at the point of publication (which usually happens several months after the last word has been added to the database), and would certainly be eclipsed by a rival title whose updating cycle led to a shiny new edition two years after your own. It is a reasonable hypothesis that social media, blogging, and other features of Web 2.0 are accelerating the pace of language change, so a dictionary whose inventory of headwords is five years out of date will be seen by users as deficient. But ease of updating creates its own pressures for the publishers of online dictionaries, as users' expectations become more demanding.

Macmillan currently updates its dictionary on a quarterly cycle, and the question of whether four updates a year are enough is regularly revisited. The only way to get journalists interested in a new or revised dictionary is to tell them about bizarre, scandalous, or otherwise newsworthy words which have been added, but for lexicographers the updating process is more complex (and more interesting) than this. For sure, new words, meanings, and phrases are added (typically at a rate of around 120 to 150 per update at Macmillan), and notwithstanding the unlimited space available to us - judgments still have to be made on the relevance and worth of novel items on the candidate list: 
although we can be more inclusive than before, as a general purpose learner's dictionary we can't justify including material which we judge to be too parochial (with a very restricted user group), too highly technical, or too ephemeral. The regular update cycle also provides opportunities for us to expand coverage of "other Englishes" (vocabulary common in the less dominant varieties of English worldwide) and of "sublanguages" (vocabulary specific to particular domains or disciplines), and a recent innovation is for updates to have a particular theme. Thus, as well as the usual task of adding newly-emerging general material, each update will focus on one specific domain or variety.

But that is the easy part, and there is more to keeping a dictionary up to date than just adding the latest words. Other tasks include: monitoring the dispersion of words or meanings (a word initially used only by American speakers, and therefore labelled as American English, may have become a common usage throughout the English-speaking world); removing dated references from example sentences (the original MED had several examples which included the word "cassette" - still a current technology when the dictionary was being compiled at the end of the 1990s, but now very dated); noting changes in word frequency (MED identifies high-frequency words with a system of stars: most of these ratings are stable, but some words - such as fax or video recorder - have become much less frequent, so they lose their stars, while others - like genetics, or tweet, or the verb use of text - have become core vocabulary items and need upgrading); and taking account of changes in grammar (such as the growing use of the preposition "of" following bored, now almost as common as the more traditional "with", or the prepositional use of because in informal sentences such as "I'm going to bed early because exhausted.").

But perhaps the biggest challenge is ensuring that the definitions of familiar words keep pace with changes in the real world. A meeting, for example, used to be exclusively a face-to-face affair, with participants gathered in the same place, and the definition reflected this. No longer: phone meetings, Skype 
conferences and the like mean that the word's scope has expanded, so the definition needs to accommodate these new uses. The changing use of the word camera provides a good example of the challenges involved in staying up to date. When MED was first published, the default meaning of camera was still the dedicated device which took pictures using photographic film, but the dictionary also included an entry for digital camera. Fifteen years on, there have been two big changes. First, cameras using film are now a niche technology, and we tend to identify them using the term analogue camera - an entry we needed to add to the dictionary. Secondly, the majority of photos are now taken not on a discrete device called a camera, but using the technology built into a smartphone or tablet. All of this had to be taken into account in the dictionary (and the entry for smartphone too will need updating, as this becomes the default type of phone). Users may have been more forgiving of a print dictionary which wasn't quite on top of all this - as if lagging a little behind changes in the real world were a guarantee of the dictionary's seriousness and "authority". No longer: a user failing to find in your dictionary a word they know and use - with its most current meaning - is likely to conclude not that the word isn't yet "important" enough to make it into the dictionary, but that the dictionary is not up to scratch.

\section{WHAT NEXT?}

Dictionary publishing is going through a turbulent period, and no-one really knows how things will look in ten years - even five years - from now. One of Macmillan's current preoccupations is how best to integrate its various dictionary resources. These include dictionaries of collocations and phrasal verbs, and a crowdsourced "Open Dictionary" with thousands of user-supplied entries, and the goal is to make them all available through a single search box. Achieving a really elegant solution - so that users always arrive, with minimal effort, at the entry most appropriate to their needs - is not a trivial task. Beyond that, we will continue, along with others working in this field, to look at new 
ways of exploiting the opportunities which digital media offer for providing a better and more relevant service to our main user-group.

How things will develop in the longer term is anyone's guess. When printed encyclopedias were superseded by online ones, this did not simply involve a straight swap from a paper resource (like Encyclopaedia Britannica) to a digital one (like Wikipedia). People searching for the kind of information which they used to seek in Encyclopaedia Britannica are now most likely to start from a search engine (and they may or may not end up in Wikipedia). The same applies to lexical data: we cannot assume that the story ends with paper dictionaries merely being replaced with digital ones. Judy Pearsall has observed that "For dictionaries to have lasted within so many human cultures for so long, it is surely not presumptuous to suggest that dictionaries must fulfil some essential human need, and that therefore, by implication, their future is secure" (Pearsall 2013: 2). But she goes on to demonstrate that this would be a dangerous assumption. The "essential human need" will likely continue for some time but whether these needs are met in the future by anything resembling a dictionary is another question.

\section{REFERENCES}

Nesi, H. (2009): Dictionaries in Electronic Form. In A.P. Cowie (ed.): The Oxford History of English Lexicography, Volume 2: 458-478. Oxford: Oxford University Press.

Nesi, H. (forthcoming): The demands of users and the publishing world: printed or online, free or paid for? In P. Durkin (ed.): The Oxford Handbook of Lexicography. Oxford: Oxford University Press.

Pearsall, J. (2013): The future of dictionaries. Kernerman Dictionary News 24 (July 2013): 2-4.

Rundell, M. (2013): Redefining the Dictionary: from print to digital. Kernerman Dictionary News 24 (July 2013): 5-7. 


\section{MACMILLAN ENGLISH DICTIONARY: KONEC TISKA?}

Prispevek predstavlja prehod slovarja Macmillan English Dictionary (MED) iz tiskanega v spletni medij s poudarkom na odločitvi, da bo slovar na voljo zgolj v spletni obliki. Pojasnjeno je ozadje odločitve, ki je povezana s tehnološkimi spremembami ter spremembami v navadah in potrebah slovarskih uporabnikov. Ali je bila takšna poteza neizogibna? Bodo podobno pot (prej ali slej) ubrali tudi ostali izdajatelji slovarjev? Predstavljen je razmislek o slabih plateh opustitve tiskane različice slovarja in prednostih digitalnih medijev. Splet sicer ponuja mnoge čudovite priložnosti (od katerih so številne še neraziskane), vendar pa prinaša tudi nove zahteve. Slovarski uporabniki imajo danes na voljo mnogo prostodostopnih strani referenčnih virov in s tem veliko izbire pri iskanju leksikalnih informacij. Ravno zato so založniki pod pritiskom, da morajo nenehno dodajati nove vrste vsebin, izboljševati kakovost oblikovanja slovarskih vmesnikov ter s tem uporabniško izkušnjo in - kar je najpomembneje - ohranjati vsebino aktualno, tj. čim hitreje ponuditi informacije o spremembah v jeziku. Kot je prikazano v prispevku, je posodabljanje slovarja precej več kot le dodajanje novih besed. Med izdajatelji slovarjev, zlasti med komercialnimi založbami, ki si ne morejo privoščiti izgub, je selitev v digitalni medij povzročila nemir; trenutno vlada precejšnja negotovost o dolgoročnem preživetju slovarja kot avtonomnega vira, kakšnega vsi poznamo. Kljub temu je zaključek prispevka optimističen: komunikacijske potrebe ljudi bodo tudi v prihodnosti zagotavljale potrebo po kvalitetnih leksikalnih podatkih - razlika bo le v tem, da bodo ti podatki ponujeni in se bo do njih dostopalo povsem drugače, kot smo bili vajeni doslej.

Ključne besede: tiskani slovar, digitalni medij, splet 2.0, vključevanje novih vsebin, posodabljanje slovarja 
To delo je ponujeno pod licenco Creative Commons: Priznanje avtorstvaDeljenje pod enakimi pogoji 2.5 Slovenija.

This work is licensed under the Creative Commons Attribution ShareAlike 2.5 License Slovenia.

http://creativecommons.org/licenses/by-sa/2.5/si/

$$
\text { (c) }
$$

